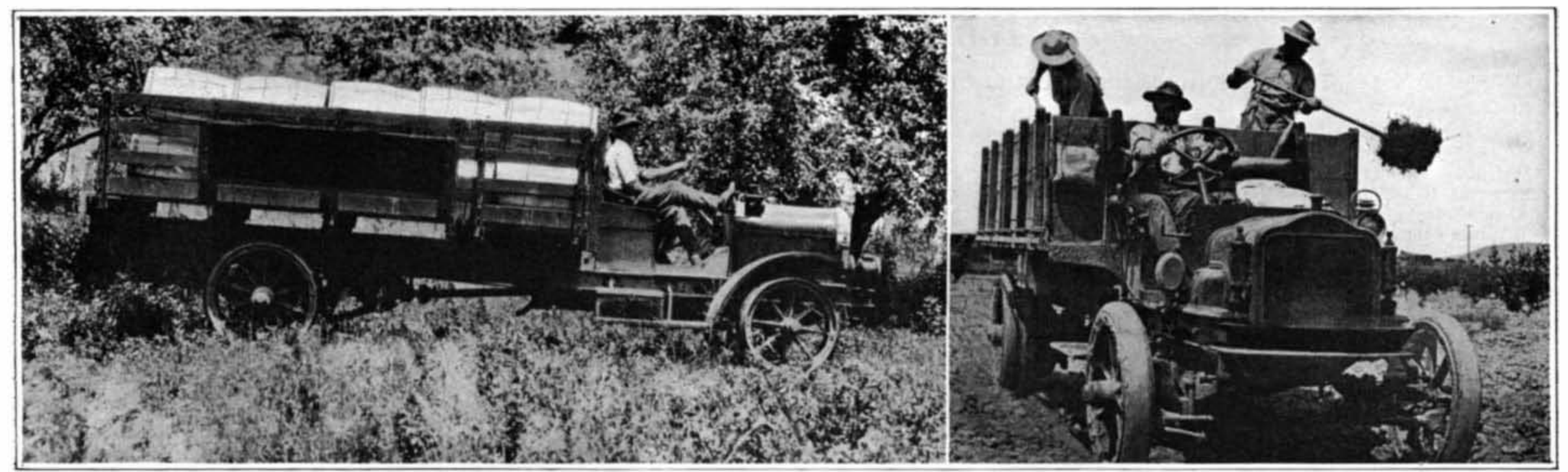

Left: A truck that was used to do all the hauling for a mountain orchard, and that came through with flying colors. Right: Using a motor truck to deliver manure to the point of final deposit

Two of the many tasks which a motor truck can perform cheaply and efficiently for the orchardist

Motor Trucks in Orchards By Arthur L. Dah

N ATURE is slow in growing to maturity fresh fruits, but once they have reached that state of perfection they deteriorate more or less rapidly, and the greatest task of the orchardist is in marketing his fruit crop in the quickest possible time and with the least amount of spoilage.

The time of harvest for most fresh fruits is limited to a month or so, and the most bountiful crop will not put dollars in the bank unless the fruit is delivered to a buyer in good condition; and in aiding the fruit grower to harvest all of his crop and make delivery to the purchaser in the best possilble condition, the motor truck is playing an important part in all sections of the country.

In modern times a large proportion of the fruit grown in many sections of our country is sold to canneries, and these canneries have very strict and rigid standards for fruit, and the prices paid for deliveries made by orchardists are based upon those standards. In too many cases fruit growers living some miles from the cannery have left home with a load of fresh fruit in good condition, but on account of the heat of the sun and the length of time required to reach the delivery point with a team, the freshness of the fruit was largely lost and the owner was severely penalized for this condition. Now this orchardist may have devoted as careful and intelligent attention to the production of that fruit crop as any of his neighbors, but because his transportation facilities were slow and inadequate, he suffered the loss of a large share of the profit he should have had.

The first point of superiority of trucks for orchard use is speed in making deliveries. A truck, even though loaded to capacity, can make better time than horsedrawn vehicles, and in the movement of a large tonnage of perishable fruit, this might mean the handling of double the amount of fruit in the same time, compared to horses. The saving in time in making deliveries is in proportion to the distance hauled, for the longer the haul the more time saved, for the truck can maintain a steady speed over the entire distance and keep it up for many round trips, while horses naturally tire.

As an example of the time saved in using trucks for delivering fruit the following experience was related hy one of the owners of the Harrison Nurseries, of Berlin, Md.

"Werlin, Md. transporting fruit, particularly peaches, from orchards to our packing plant Peaches must be handled quickly, and it is also important that we make our schedule with the railroads. At packing time we employ from 100 to 125 people from 100 to 125 people, wendent upon our trucks. Recently one of our motor trucks enabled us to transport a force of men from Berlin to Easton, 75 miles

away, pick $\$ 16,000$ worth of peaches and return in six days. Another of our trucks this season made thirteen trips in one day between one of our orchards and our packing plant, a distance of two miles, carrying 175 baskets of peaches on each trip, besides two other trips carrying employees.'

Another peach grower reported that in the old days when he used a team he had to stirt for market, 10 miles away, between 12 and $2 \mathrm{~A}$. MI. and got back toward noon. The trip with the wagon had to be very slow to prevent bruising. Now, however, with an auto truck equipped with good springs, shock absorbers and pneumatic tires, the most delicate peaches are carried into market within an hour, and other stuff in half the time. He starts out at 5 A. M., is unloaded at market by 6 , and is back at the farm a little after 7 , with the whole day ahead of him for other work.

Motor trucks not only enalole the fruit grower to haul his crop in less time, but he can haul a great deal more to a load than with any other mode of conveyance. This means that in many cases the truck will handle in one load what woulel have been two or more loads with a team, and in this day of labor shortage this is an important advantage.

California is a great fruit country, and there are some very good roads there, so it is to be expected that motor trucks should readily demonstrate their carrying capacity there to the best advantage. There are hundreds of examples of enormous loads of fresh fruit hauled from one point to another in California. but a representative one is the experience of a Sant: Clara orchardist who hauled, on a motor truck and a trailer, 16,000, pounds of fresh apricots from his orchard to the canner'y, a distance of six miles. A part of this haul was made over the soft ground of an orchard before the county road was reached, but thi outfit operated throughout the picking season and never gave any trouble.

Throughout the various fruit districts of California motor trucks can be seen engaged in doing all kinds of work from hauling manure to fertilize the soil to hauling the fruit crop to market. Many owners have several types of bodies for their trucks, so that they can (Continned on page 581)

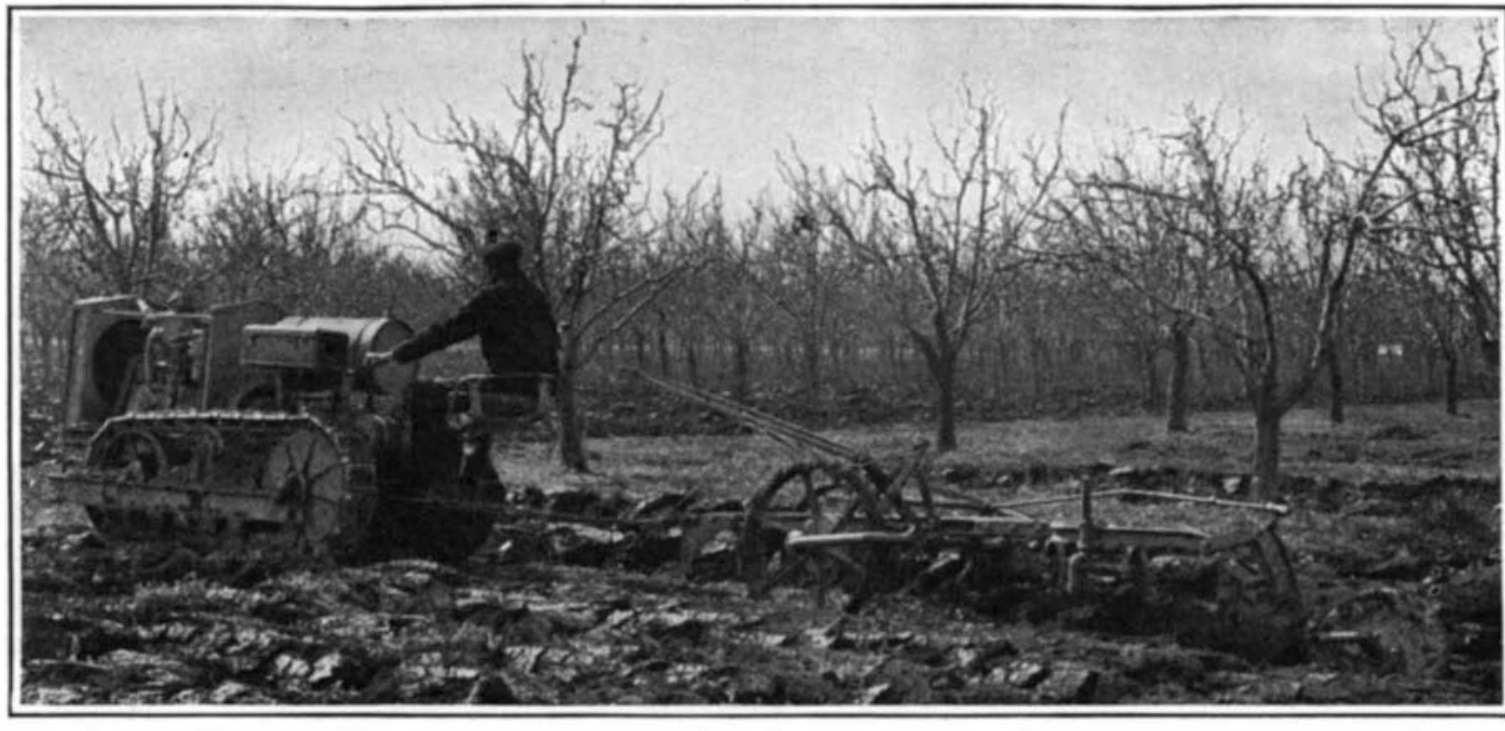

A gang of moldboard plows at work in a California orchard, preparing the ground for a cover crop that conserves the moisture and furnishes a rich supply of fertilizer when ready to be plowed under
Crops for Our Orchards By H. A. Crafts

THE use of cover crops in California orcharding $\boldsymbol{I}$ is very important to successful culture, and its value is being better appreciated the more it is practiced. Climatic conditions are among those entering into the problem. The rainless summers of California render conservation of moisture very essential to the production of any crop whatever. And it is just as essential to a full fruit crop as to any other. Cover crops may be made to conserve moisture in ore than one direction.

Shading, mulching, and cultivation may be mentioned as being among these.

The benefits of cultivation, of course, accrue automatically. You cannot very well raise a cover crop without first plowing the ground, harrowing, cultivating, disking it; and all this stirring of the soil tends strongly to conserve moisture. Well-plowed and cultirated ground lies in the best shape possible to receive, retain and distribute the moisture resulting from current rainfall. It also stinulates the rise of the hidden moisture, stored in the sub-strata of the soil. Thus it aids the accumulation of necessary moisture from two obposite directions, and thus seems to exercise a most valualle and well-ordered function.

Again, a cover crop provides a tery feasible method of refertilization. For the crop, in its state of fullest maturity, may be plowed under, and made to supply that very necessary substance to the soil, known to science as humus, but which in plain, unvarnished English means simply regetable matter in process of decomposition.

The ancient illusion under which some orchardists labor, even at this late day, that a fruit tree that once grerminates, springs up, fiourishes and produces fruit, is il permanent institution; and that the principal duty of the orchardist is simply to harvest a crop of fruit, year by year, from these permanent trees, seems to be slowly vanishing from pomological psychology. The truth of the matter is that the fruit tree should be nursed and nourished and fostered even much more faithfully than a mere annual crop of corn, or potatoes or beans. This because the fruit tree stands guard ceaselessly, night and day. summer and winter, in sunshine or rain, being exposed to the constant play of the elements, the assaults of disease and pestiferous insects, and so forth.

The life tenure of the peach tree, the orange tree, or the plum tree is perennial, while that of the stalk of corn is only annual. The stalk of corn germinates, takes root, springs up and flourishes only through the brief period of a seasonal career. About September it has finished its cycle; the farmer comes along with a corn cutter, and the whole life of that stalk ceases, save in the golden kernel (Continued on page 582 ) 
pairs the health and wellbeing of every | barrier to true representation, be it social, community, and even threatens our very form of government.

Heretofore we have prided ourselves upon our literacy. We have taken it for granted that every American could read and write. But the result of the draft showed us that nearly a third of the picked manhood of the nation were unschooled to the point where they could not be accepted as soldiers because they could not understand military instructions of the most elementary sort. Scores of thousands could not distinguish between right hand and left hand. Those who could not read a word included native born whites and negroes as well as foreign-born.

Slight provision is made in our schools for the needs of the adult. In our public schools, moreover, due to scanty pay, there is a present lack of sixty thousand teachers. This is the condition facing the administrators of education for children under sixteen or eighteen. The additional problem of teaching the adult foreign born illiterate, the unschooled mountain white, and the negro is so vast that though every one of our seven hundred and fifty thousand public school teachers were to relinquish their work with children and should devote themselves to the instruction of adults who cannot read and write, even then we should not have a force of teachers sufficient to cope with the situation.

Illiteracy therefore is manifestly not the sole business of the schools and the school authorities. It concerns ever American. It affects especially the employer, whether in industry or in the household. Half of the illiterates are women, many of whom are employed in factories or in homes.

Evening schools reach only a few of the most ambitious, for the majority of those who cannot read or write or speak our language cannot go to school. Evening schools in New York City have succeeded in the course of a year in reaching scarcely one-half of one per cent of the hundreds of thousands of illiterate aliens. The reasons are many: Industrial fatigue, fam ily obligations, lack of means, and especially faulty school methods and failure to arouse and maintain interest

$A$ practical and effective method of teaching the illiterate to read is the in stitution of public school classes in the places of employment. The first workers' class was instituted in 1913 in New York City. There are now more than thousand such classes in industrial establishments everywhere. In Chicago alon there are several hundred such classes in successful operation. It is not practicable to carry on these clissses with complete success unless provision is made for at tendance without loss of pay during day light hours. An hour a day five days week should be given during the period of instruction.

The latest developments in methods of instruction are Self Help Lessons in American to be put into the hands of the learner himself, and so arranged in method and manner as to be interestin and capable of being used without the ai necessarily of a trained instructor. Such elementary graded progressive lessons provide a language machinery which an adult can use successfully with slight help perhaps from a child who goes to American public school or from some friend who has had a little schooling. Such lessons can eventually be put in the hands of everyone.

It is practicable to develop a One Language Nation as well as a literate nation, but this needs the informed and hearty teamwork of directors of industry, leaders of labor, school authorities, legislators, the press, and the general public.

Democracy is measured by ability each to share in the thought of all. Today thought is shared by means of the printed word. Therefore inability to read and absence of the reading habit is a industrial, or political. Yet we persistently avoid this obvious fact in our consideration of industrial relations and methods of civil government. The problem of the elimination of illiteracy from the United States is the problem of the most vital importance to us all, for it is asic to national prosperity and is the only means of unifying the nation.

\section{Motor Trucks in Orchards} (Continued from page 567)

be used for different classes of work. In stance, it is found desirable to have a wide platform on the chassis, while for other uses a closed or box body is required. In the raisin district of Fresno County motor trucks are used in large numbers to haul the grapes for drying and again from the drying fields to the packing houses and store rooms. The same is true of the prune districts of the Santa Clara Valley, while in the cherry center, in Alameda County, the trucks are largely used to haul the fresh fruit to market or to the cannery. Lake County is famous for its pears, and here, too, the motor truck is playing an important part in solving the transportation problems of districts of southern California, and the olive district of Butte County, motor trucks are depended upon to move the fruit from the orchards to the packing sheds.

As an example of the adaptability of the motor truck to different kinds of hauling jobs, we have the experience of Mr. Charles W. Mann, a fruit grower of Methuen, Mass. Mr. Mann has four different bodies for his $11 / 2$-ton truck, and since its purchase in 1911 this truck has run over 100,000 miles. He uses it to collect thousands of barrels of apples from orchards within a radius of 10 to 15 miles and then to deliver them to nearby markets, to freight cars, or to Boston, truck made two round trips to Boston daily for four weeks, averaging 120 miles a day.

With a double-deck body, Mr. Mann's truck will carry 50 bushels of strawberries or tomatoes without bruising them and in one season he sold from it 50,000 baskets of berries and 4,000 bushels of tomatoes. The truck also hauled over 150 tons of hay in one season.

That motor trucks will reduce transportation costs has been shown in the experience of many owners. Mr. H. B. Wayland operates an orchard near Heards, Va., and the roads in his vicinity are not particularly good and some of them have high grades. In the old days Mr. Way land used several four-mule teams for hauling to and from his orchard, and he estimated the daily cost of each of these teams at $\$ 5.22$ even when idle. He hesitated about purchasing a truck on accoun of the condition of the roads, sometime very muddy, but he finally purchased 3-ton motor truck and in five months this truck covered 2,160 miles before winter closed the roads. The cost figures, in spite of the fact that this five months work was of the roughest type, including regular road freighting and logging over narrow mountain trails on short, hard hauls, showed a net saving of 10 cents per ton-mile over mule and wagon haulteams were sold and the entire haulin work of the orchard done with the truck In the cranberry marshes of New Jersey the motor truck is doing good service and in spite of the slippery bogs and the wide stretches of sands, the truck is supplanting animal teams. One such truck made from 20 to 25 complete $41 / 2$-mile trips daily during the picking season The truck has replaced five teams and approximately 100 per cent.

In many cases the use of motor trucks has enabled fruit growers to save their hauling fruit trays, or baskets, for inthe growers. In the orange and lemon 11. miles distant. In one season this age, and after this experience the mule surpassed the record of the teams by
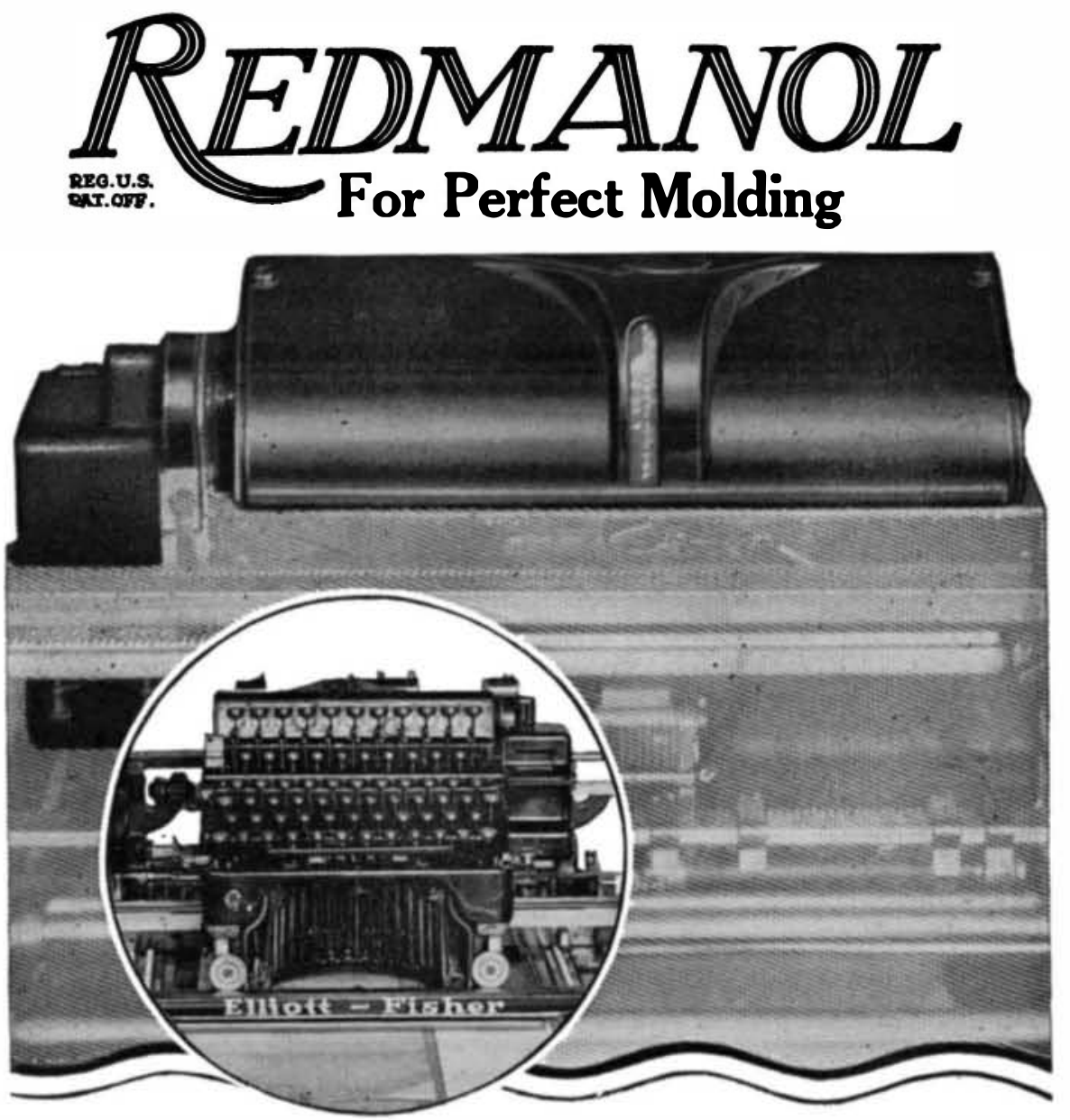

\section{Elliott-Fisher and many others}

7 HE CLOSE-UP shows how Elliott-Fisher 1 use REDMANOL in their nationally known bookkeeping machines. REDMANOL, for many others, is obviating the necessity for die-casting, stamping, shaping, and finishing. Its many admirable qualities (in addition to those briefly given below) make it ideal for a limitless variety of uses in any makers' products. Frequently it markedly cuts down production time while lowering production costs. Alway it is good-looking and exceedingly durable. Very likely you could with advantage use this perfect molding compound in your product. Just ask us. We will tell you specifically what REDMANOL will do for you.

\section{We Help Manufacturers}

Our laboratories are constantly engaged in working out new applications for forward-looking manufacturers. It implies no obligation to submit your problem for solution. Address Department 87.

Redmanol Chemical Products Co. 636 W. 22nd St. Chicago, U. S. A.

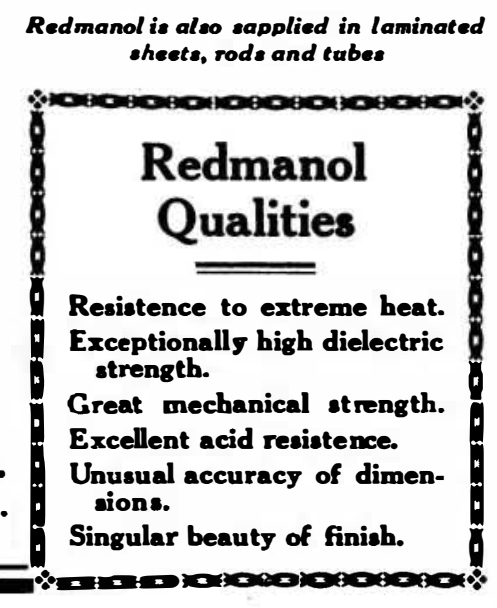

Now Ready $A$ New Book on a New Subject

BEHIND THE MOTION-PICTURE SCREEN

$\mathrm{H}_{\text {are }}^{\mathrm{KEE} \text {, at last, is the wonder book of the screen. It takes the reader into that marvelous land where fime }}$ up in proper turn, from the planning and writing of the scenario to the projecting of the tilished film on
the screen in the picture.

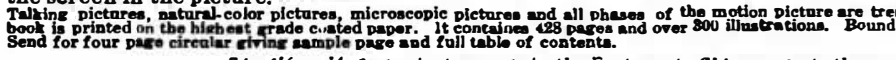

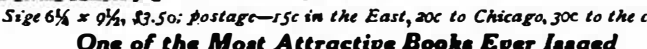

One of the Moat Attractive Booke Ever losaed
SCIENTIPC AMERICAN PUBLISHING COMPANY 233 BROADWAY, NEW YORK 


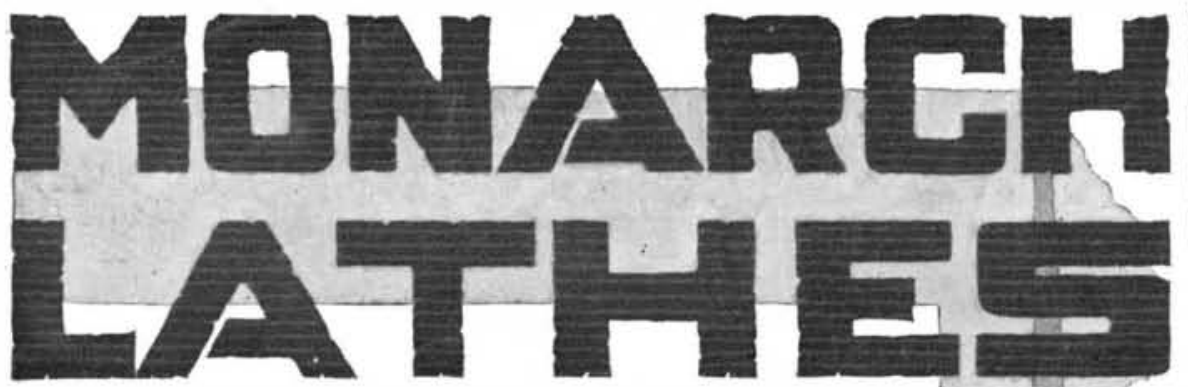

The Monarch Organization is proud of the fact that it builds and sells more Monarch's each year than there are lathes produced by any other high grade manufacturer.

And the Monarch Organization is more proud of the fact that a large percentage of their lathes are sold to present users of Monarch lathes who purchase for replacement or additional equipment. It is the real proof of our policy of guaranteeing "Satisfaction to the Purchaser".

The Monarch Machine Tool Co. Sidney 123 OAK STREET

\section{Ohio}
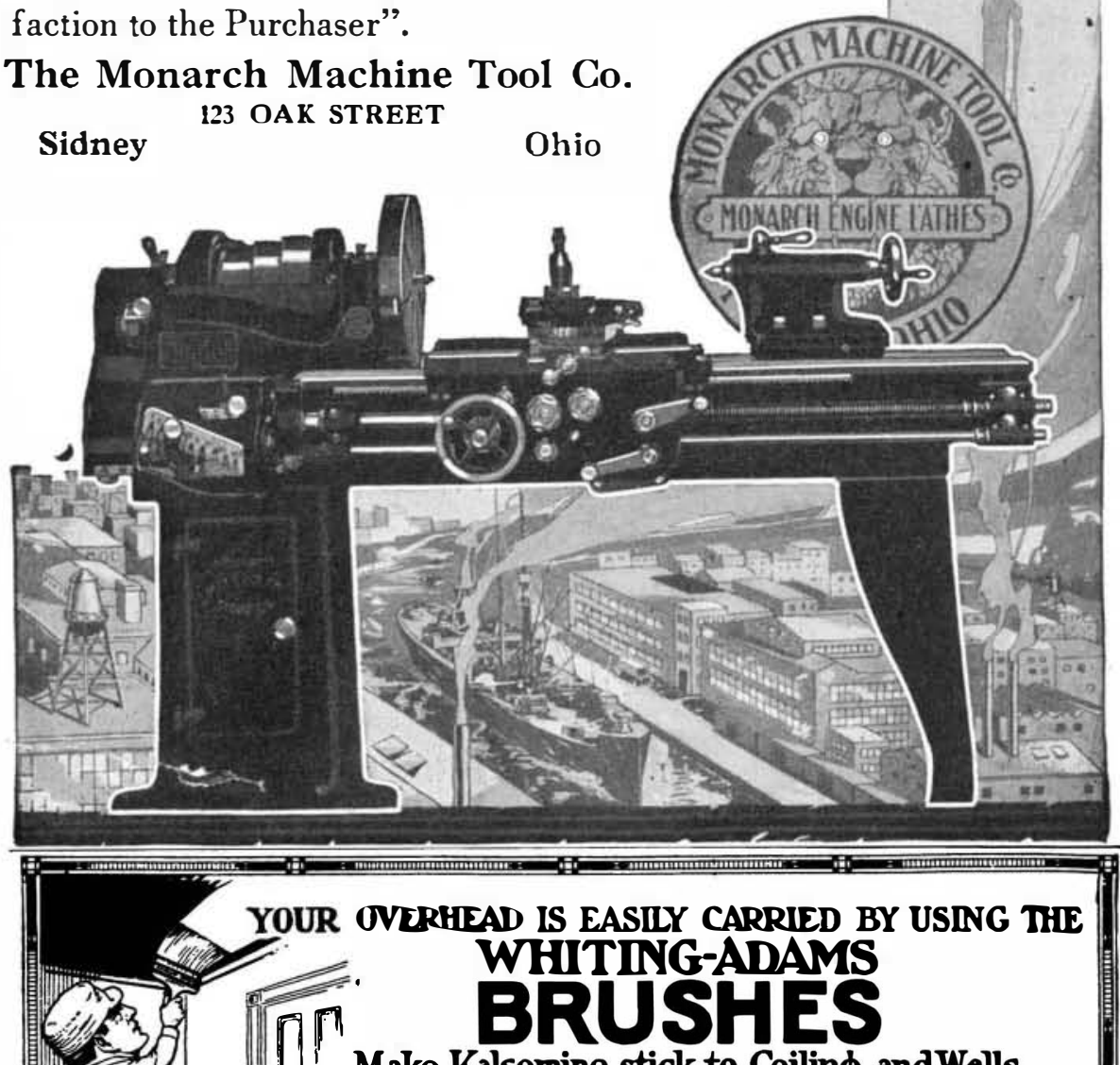

Make Kalsomine stick to Ceiling andWalls.

Positively no let $\$ 0$.

Their use insures a permanent alabaster like surface.

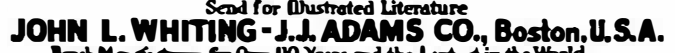

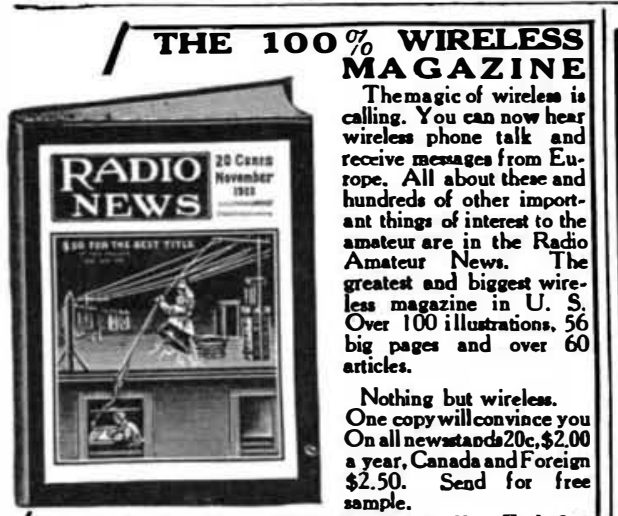

Redio Amalear Mewro. 237 Fulton Street, New York City

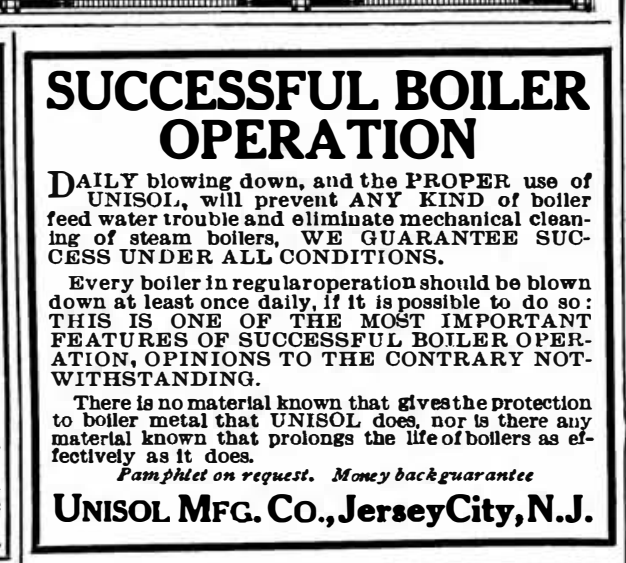

Whatever Your Question;-be it the pronunciation of Bolshevili, the spelling of a puzzling word, the location of Murman Coast-the meaning of blighty, etc, this Supreme Authority WEBSTER'S NEW INTERNATIONAL DICTIONARY (A) (I)

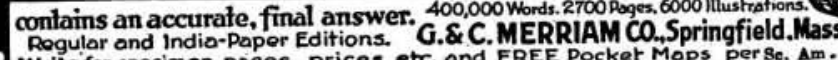

crops when weather conditions are unfavorable. In 1918 early rains in California spoiled thousands of tons of drying prunes, and one grower rescued a $\$ 25,000$ move them quickly with his motor truck.

Cover Crops for Our Orchards (Continued from page 567) husbandman for the renewal of the corn crop next year.

Not so with the fruit tree. It must serve long years; bear patiently all the vicissitudes of vegetable life; produce fruit abundantly, even in the extremity of old age.

Nor is the fruit tree indifferent to man's care and attention. It smiles its gratitude in terms of vigorous wood growth, luxuriant leafage, a profusion of beautiful spring bloom, and finally a crop of fruit richly tinted and colored to please the eye, and gushing with pleasant juices, wherewith to gratify the appetite of man. Cover crops may be used handily and effectively in the art of mulching. Mown cover growths gathered about a tree, a proper depth, may be made to serve various purposes-stifle weeds or foul growths that may have sprung up around the tree, conserve moisture by preventing too rapid evaporation; and the refertilizatree, where it is most needed

Rainfall may thus be absorbed and held in suspension for the better nourishment of the tree; moisture from lower sources may be also brought up and made to do good service. And, as in a hundred other instances the farm tractor comes upon the scene as a most efficient tool to It is both handy to use, and effective in its action. One of the most awkward phases of orchard culture that has come under my own observation was the cultivation of orchards by means of horsepower. Time and again I have watched some unlucky wight tooling a plow, a walking plow at that, and a pair of farm horses beneath the umbrageous roofage of a California orchard. The plowman, grasping tenaciously the two plow handles, plodding mile after mile in a muddy sticky furrow; now watching the plow and then throwing a quick glance to hi team, the occasional jerk on the lines which are hooked over his own neck be cause his two hands are otherwise en gaged, and then emitting a blue streak of profanity for the better guidance of his team and the delectation of chance passersby, was the scene in outline.

A dull and sordid task calculated to exhaust the body and jar the moral fibe with bitter memories. Then the vain attempts to induce those poor horses, as the slow furrowing proceeded, reverently to tree tops in order that the plowing might be carried nearer the vital parts of the trees

But why recall those scenes of rusti toil and tribulation of the spirit, when they have passed, or are about to pass into tion?

And now we behold this emancipated son of toil seated cheerfully upon the throne of the farm tractor, gently steerin the apparatus between innumerable rows of fruit trees, turning up the mellow mold through which he once plodded with leaden feet and heavy heart. Gently he guides the machine up beneath the lowbending branches until he seems to be mminent danger of barking the tree.

But no: Never a bark! Neither is the tractor asked to bow its head; because it is headless and has an orchard top to it. Now as to various plants that are adapted to cover crops under Oalifornia orchard conditions: There is Melilatus, or Bitter clover. This is an early starter, makes a good growth during the
winter, sometimes attaining the goodly
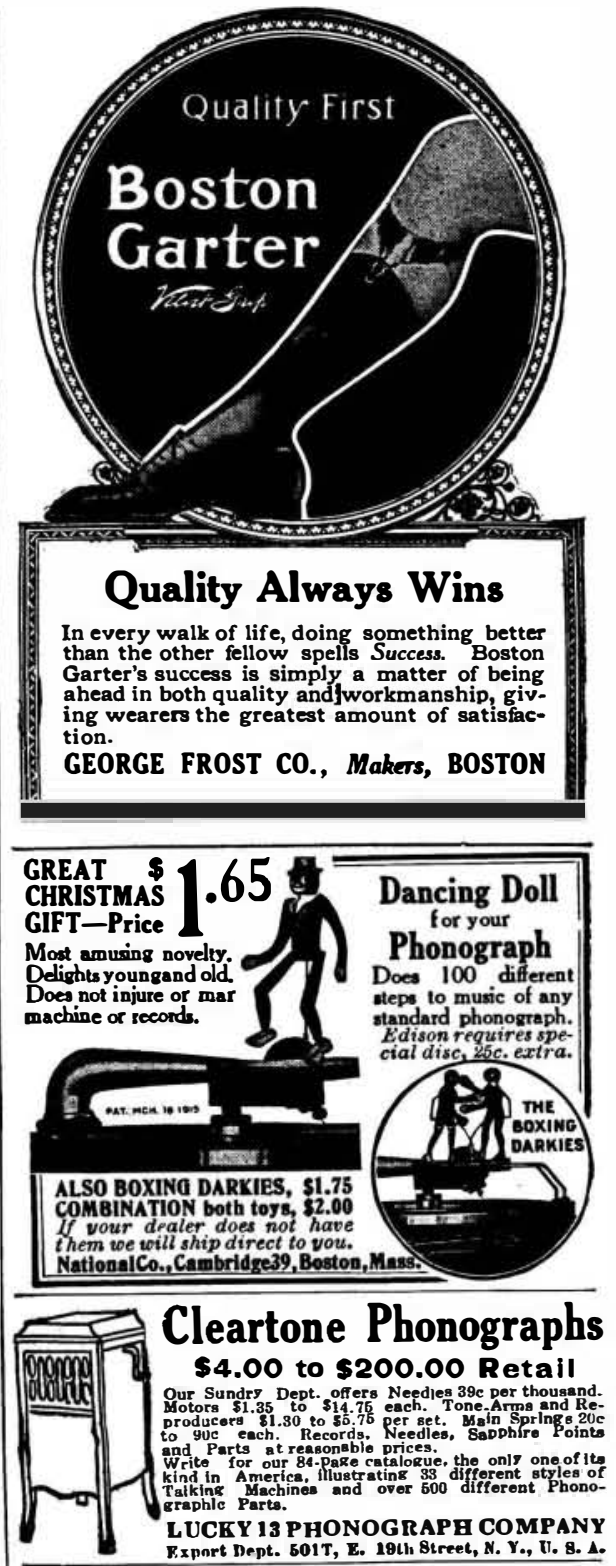

WELL ${ }_{\text {PAIS }}^{\text {DRIING }}$ WELL

Own a machine of your own. Cash or easy
terms. Many styles and sizes for all purposes Writc for Circular.

WILLIAMS BROS., 434 W. State St., Ithaca, N.Y.

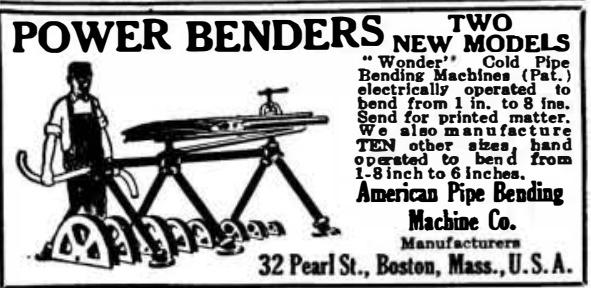

MASON'S NEW PAT. WHIP HOIST Comparative cost 40 foot lift:
By elevator 5 men, 50 bale: of wool per hour
By Mason's Whip- 3 men, 90 bales of wool per hour One rope hoists, lower and holds the load Manufactured by vOLNEY W.MASON \& CO., Inc.
Providence. R. I.. U. S. A.

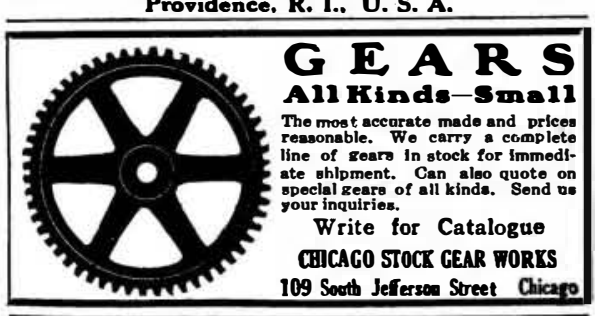

96 Page Catalogue of

SCIENTIFIC AND TECHNICAL BOOKS

Listing 2500 titles on 500 sabjects

$\mathrm{S}_{\text {in print. This catalogue is the latest and }}^{\text {ELECTED from more than }}$ best list of technical and scientific literature lishing business are most severe and it is with
difficulty that many books can be obtained. For this rean this timely catalogue of books w

$$
\begin{aligned}
& \text { Write to-day for your copy. } \\
& \text { Sent free on application. }
\end{aligned}
$$

SCIENTIFIC AMERICAN PUBLISHING CO. 233 Broadway, Woolwortb Bldz. New Yort, H. 